\title{
Nitrogen fluxes from irrigated common-bean as affected by mulching and mineral fertilization
}

\author{
Márcia Thaís de Melo Carvalho(1), Beáta Emöke Madari(2), Wesley Gabriel de Oliveira Leal(2), \\ Adriana Rodolfo da Costa( ${ }^{(3)}$, Pedro Luiz Oliveira de Almeida Machado(2), Pedro Marques da Silveira(2), \\ José Aloísio Alves Moreira( ${ }^{(4)}$ and Alexandre Bryan Heinemann ${ }^{(2)}$
}

\begin{abstract}
(1)Embrapa Arroz e Feijão/Centre for Crop Systems Analysis, University of Wageningen, Post Office Box 430, 6700 AK Wageningen, The Netherlands. E-mail: marcia.carvalho@embrapa.br (2)Embrapa Arroz e Feijão, Caixa Postal 179, CEP 75375-000 Santo Antônio de Goiás, GO, Brazil. E-mail: beata.madari@embrapa.br, wesley.leal@embrapa.br, pedro.machado@embrapa.br, pedro.silveira@embrapa.br, alexandre.heinemann@embrapa.br (3)Universidade Estadual de Goiás, Unidade Universitária de Santa Helena de Goiás, Via Protestato Joaquim Bueno, no 945, Perímetro Urbano, CEP 75920-000 Santa Helena de Goiás, GO, Brazil, E-mail: adriana_rodolfo@yahoo.com.br (4)Embrapa Milho e Sorgo, Caixa Postal 285, CEP 35701-970 Sete Lagoas, MG, Brazil, E-mail: jose.aloisio@embrapa.br
\end{abstract}

Abstract - The objective of this work was to measure the fluxes of $\mathrm{N}_{2} \mathrm{O}-\mathrm{N}$ and $\mathrm{NH}_{3}-\mathrm{N}$ throughout the growing season of irrigated common-bean (Phaseolus vulgaris), as affected by mulching and mineral fertilization. Fluxes of $\mathrm{N}_{2} \mathrm{O}-\mathrm{N}$ and $\mathrm{NH}_{3}-\mathrm{N}$ were evaluated in areas with or without Congo signal grass mulching (Urochloa ruziziensis) or mineral fertilization. Fluxes of $\mathrm{N}$ were also measured in a native Cerrado area, which served as reference. Total $\mathrm{N}_{2} \mathrm{O}-\mathrm{N}$ and $\mathrm{NH}_{3}-\mathrm{N}$ emissions were positively related to the increasing concentrations of moisture, ammonium, and nitrate in the crop system, within $0.5 \mathrm{~m}$ soil depth. Carbon content in the substrate and microbial biomass within $0.1 \mathrm{~m}$ soil depth were favoured by Congo signal grass and related to higher emissions of $\mathrm{N}_{2} \mathrm{O}-\mathrm{N}$, regardless of $\mathrm{N}$ fertilization. Emission factors $(\mathrm{N}$ losses from the applied mineral nitrogen) for $\mathrm{N}_{2} \mathrm{O}-\mathrm{N}(0.01-0.02 \%)$ and $\mathrm{NH}_{3}-\mathrm{N}(0.3-0.6 \%)$ were lower than the default value recognized by the Intergovernmental Panel on Climate Change. Mulch of Congo signal grass benefits $\mathrm{N}_{2} \mathrm{O}-\mathrm{N}$ emission regardless of $\mathrm{N}$ fertilization.

Index terms: Cerrado, climate change, greenhouse gas, $\mathrm{N}$ fertilization, nitrous oxide, no-tillage.

\section{Fluxos de nitrogênio em feijoeiro irrigado influenciados pela cobertura morta e a fertilização mineral}

\begin{abstract}
Resumo - O objetivo deste trabalho foi medir os fluxos de $\mathrm{N}_{2} \mathrm{O}-\mathrm{N}$ e $\mathrm{NH}_{3}-\mathrm{N}$, ao longo de uma safra de feijoeiro irrigado (Phaseolus vulgaris), influenciados pelo uso ou não de cobertura morta e fertilização mineral. Os fluxos de $\mathrm{N}_{2} \mathrm{O}-\mathrm{N}$ e $\mathrm{NH}_{3}-\mathrm{N}$ foram avaliados em áreas com ou sem cobertura de braquiária (Urochloa ruziziensis) ou fertilização mineral. Os fluxos de $\mathrm{N}$ também foram medidos em uma área nativa de Cerrado, a qual serviu como referência. As emissões de $\mathrm{N}_{2} \mathrm{O}-\mathrm{N}$ and $\mathrm{NH}_{3}-\mathrm{N}$ foram positivamente relacionadas ao aumento da umidade e das concentrações de amônio e nitrato na área cultivada, na camada até $0,5 \mathrm{~m}$ de profundidade do solo. O conteúdo de $\mathrm{C}$ no substrato e a atividade microbiana na camada até $0,1 \mathrm{~m}$ de profundidade do solo foram favorecidos pela presença da palhada de braquiária e estiveram relacionadas com maiores emissões de $\mathrm{N}_{2} \mathrm{O}-\mathrm{N}$, independentemente da fertilização nitrogenada. Os fatores de emissão (perdas de $\mathrm{N}$ a partir do nitrogênio mineral adicionado) para $\mathrm{N}_{2} \mathrm{O}-\mathrm{N}(0,01-0,02 \%)$ e $\mathrm{NH}_{3}-\mathrm{N}(0,3-0,6 \%)$ foram menores do que o valor estabelecido pelo Painel Intergovernamental de Mudanças Climáticas. A cobertura com braquiária aumenta a emissão de $\mathrm{N}_{2} \mathrm{O}-\mathrm{N}$, independentemente da fertilização com nitrogênio.
\end{abstract}

Termos para indexação: Cerrado, mudanças climáticas, gas de efeito estufa, óxido nitroso, plantio direto.

\section{Introduction}

Common-bean (Phaseolus vulgaris L.) is an important staple food in Brazil. During the dry season in the Brazilian Cerrado, between May and September, irrigated common-bean crop covers 182 thousand hectares (National Company of Food Supply, 2013), commonly cultivated under no-tillage system on the crop residues of maize or Congo signal grass (Urochloa ruziziensis). Center pivot is the most used irrigation system, by which yields can reach up to $2.5 \mathrm{Mg} \mathrm{ha}^{-1}$, usually $40 \%$ higher than nonirrigated ones (National Company of Food Supply, 2013). Besides irrigation, high inputs of mineral $\mathrm{N}$ (mainly urea, with total amounts reaching $245 \mathrm{~kg} \mathrm{ha}^{-1}$ ) also explain the higher yields of this crop system (Posse et al., 2011). 
Environmental impacts of such an intensive crop system can be high, and its evaluation is a important step towards sustainable production.

Quantifying the emission of greenhouse gases (GHG) from crop systems is becoming increasingly important, considering worldwide trends towards full carbon accounting. Nitrous oxide $\left(\mathrm{N}_{2} \mathrm{O}\right)$ is one of the GHG which contributes to climate change. In the Brazilian agriculture, emissions of $\mathrm{N}_{2} \mathrm{O}-\mathrm{N}$ increased in $24 \%$ from 1994 to 2005, and agricultural soils are responsible for more than $95 \%$ of $\mathrm{N}_{2} \mathrm{O}-\mathrm{N}$ emissions, including direct $\mathrm{N}_{2} \mathrm{O}-\mathrm{N}$ emission sources - mineral fertilizers, crop residues, grazing animals, animal off-field produced manure, biological fixation, etc. - and indirect ones - leaching, runoff, and atmospheric deposition (Cerri et al., 2009). Local assessment of GHG emissions from Brazilian agriculture systems have been reported (Carvalho et al., 2006; Metay et al., 2007; Jantalia et al., 2008; Zanatta et al., 2010; Cruvinel et al., 2011); however, the relative scarcity of data makes it difficult to assess the overall impact of irrigated common-bean under no-tillage on $\mathrm{N}_{2} \mathrm{O}-\mathrm{N}$ and $\mathrm{NH}_{3}-\mathrm{N}$ fluxes in the Brazilian Cerrado.

The effect of no-tillage on decreasing $\mathrm{CO}_{2}$ emissions is largely known (Piva et al., 2012). There are, however, many constrains related to the exact role of this cropping system in mitigating $\mathrm{N}_{2} \mathrm{O}-\mathrm{N} /$ $\mathrm{NH}_{3}-\mathrm{N}$ emissions, especially because the impact of management on soil microbial activity (Bardgett et al., 2008) is still largely unknown. N Losses via volatilization can be high under no-tillage because the fertilizer usually has a restricted contact with the soil, due to the presence of mulch or crop residues (Da Ros et al., 2005). Additionally, large amounts of $\mathrm{N}$ can be lost via $\mathrm{N}_{2} \mathrm{O}-\mathrm{N}$ fluxes under irrigation, where denitrification is stimulated by anaerobic conditions. Rochette (2008) reported that no-tillage generally increased $\mathrm{N}_{2} \mathrm{O}-\mathrm{N}$ emissions in poorly-aerated soils, and Woodward et al. (2009) suggested that adopting reduced or no-tillage systems, in some cases, enhances the emissions of $\mathrm{N}_{2} \mathrm{O}-\mathrm{N}$ from soil, especially due to increased denitrification. However, even within presumably homogenous regions, spatial and temporal variability and range of $\mathrm{N}_{2} \mathrm{O}-\mathrm{N}$ emissions is large (Pérez et al., 2001); hence, local assessments of $\mathrm{N}_{2} \mathrm{O}-\mathrm{N}$ emissions are indispensable to estimate the overall impact of agricultural systems on GHG emissions (Reay et al., 2012).
The objective of this work was to measure fluxes of $\mathrm{N}_{2} \mathrm{O}-\mathrm{N}$ and $\mathrm{NH}_{3}-\mathrm{N}$, throughout the growing season of irrigated common-bean, as affected by mulching and mineral fertilization.

\section{Materials and Methods}

The N-fluxes measurements were made within an area cultivated with common-bean under no-tillage, irrigated via center pivot, on a clayey Rhodic Ferralsol, located at Embrapa Arroz e Feijão, in Santo Antônio de Goiás, GO, Brazil (16²9'17"S and 49 $\left.17^{\circ} 57^{\prime \prime} \mathrm{W}\right)$. Manual static chambers were used to measure $\mathrm{N}_{2} \mathrm{O}-\mathrm{N}$ fluxes, and manual open static chambers were used to measure $\mathrm{NH}_{3}-\mathrm{N}$ fluxes. Congo signal grass was desiccated with glifosate $\left(0.5 \mathrm{~kg}\right.$ i.a. ha $\left.\mathrm{h}^{-1}\right) 15$ days prior to the seeding of common-bean, in order to form mulch. In the treatments without Congo signal grass mulch, common-bean was cultivated on crop residues of maize. Common-bean ('BRS Agreste') was sown in June $9^{\text {th }}$ and harvested in September $20^{\text {th }}, 2008$. From June to August 2008, there was no precipitation, air temperature ranged from $13^{\circ}$ to $34^{\circ} \mathrm{C}$, and average daily evaporation was $154 \mathrm{~mm}$.

The effects of mulching with Congo signal grass (Urochloa ruziziensis) and of mineral fertilization (NPK) on N-fluxes were evaluated. The evaluated treatments were: common-bean cultivated with Congo signal grass mulch and fertilizer; common-bean cultivated with mulch, but not fertilized; common-bean cultivated without mulch, but fertilized; and common-bean cultivated without mulch or fertilizers. Each treatment was assessed with six manual static chambers, used to measure the $\mathrm{N}$-fluxes, each chamber corresponding to a replicate. The manual static chamber used to measure $\mathrm{N}_{2} \mathrm{O}-\mathrm{N}$ fluxes consisted of a metal base $(0.38 \mathrm{~m}$ wide $\mathrm{x} 0.58 \mathrm{~m}$ long $)$ covering a soil area of $0.22 \mathrm{~m}^{2}$ and a plastic cap ( $0.1 \mathrm{~m}$ height $)$ fixed on the metal base, similar to the chamber used by Alves et al. (2012). When closed, the volume of the chamber was $19.8 \mathrm{~L}$.

Soil chemical and physical properties were determined in $1 \mathrm{~m}$ trenches according to Silva (2009) (Table 1). Fertilized treatments received $400 \mathrm{~kg} \mathrm{ha}^{-1}$ fertilizer (5-30-15 N-P-K) applied at planting. Urea, $200 \mathrm{~kg} \mathrm{ha}^{-1}(45 \% \mathrm{~N})$ was applied via fertigation by the center pivot system: $100 \mathrm{~kg} \mathrm{ha}^{-1}$ in the $27^{\text {th }}$ day after sowing (DAS), and $100 \mathrm{~kg} \mathrm{ha}^{-1}$ at 41 DAS. During 
fertigation, the chambers and corresponding area for soil sampling were covered with plastic to prevent any chance of contamination of the treatments without $\mathrm{N}$ fertilization. For these treatments, the same amount of water without $\mathrm{N}$ was applied via irrigation. Total irrigation (via center pivot), throughout the growing period, was $419 \mathrm{~mm}$ (about $9 \mathrm{~mm}$ per event at 29 hour intervals).

Fluxes of $\mathrm{N}_{2} \mathrm{O}-\mathrm{N}$ were measured after irrigation events at June 10, 11, 12, 13, 14, 17, 23; July 1, 7, 8, 9, $11,12,13,14,16,21,22,23,24,25,26,30$; August 6, 13, 20, 28; and September 3, 10, 18. Gas samples were taken between 9:00 to 11:00 a.m., as recommended by Alves et al. (2012). Gases accumulated in the static chamber in a period of 20 min were collected using a manual vacuum pump. From one chamber in each treatment, samples were taken at five-minute intervals, during the collection period of $20 \mathrm{~min}$. Additionally, three air samples were taken to be used as controls. Soil temperature at $0.05 \mathrm{~m}$ soil depth next to the chambers was measured simultaneously with $\mathrm{N}_{2} \mathrm{O}-\mathrm{N}$ flux sampling. Concentration of $\mathrm{N}_{2} \mathrm{O}$ inside each chamber was calculated as the difference between $\mathrm{N}_{2} \mathrm{O}$ concentration in the air and $\mathrm{N}_{2} \mathrm{O}$ concentration inside the chamber. Gas samples were analyzed by gas chromatography with an electron capture detector (ECD) auto system XL (Perkin Elmer, São Paulo, SP, Brazil), calibrated with certified $\mathrm{N}_{2} \mathrm{O}$ standards of 350 and $1,000 \mathrm{ppb}$. Fluxes of $\mathrm{N}_{2} \mathrm{O}-\mathrm{N}$ were calculated according to Alves et al. (2012). When estimating total emitted $\mathrm{N}_{2} \mathrm{O}-\mathrm{N}$, negative fluxes (lower than the concentration of the air), were set to zero. Total emissions were calculated by interpolating and integrating mean fluxes over time. Unfertilized treatments were used to calculate emission factor.

Fluxes of $\mathrm{NH}_{3}-\mathrm{N}$ were quantified with manual open static chambers, each one covering $0.008 \mathrm{~m}^{2}$ of ground. These chambers were made from $2 \mathrm{~L}$ plastic bottles of $0.1 \mathrm{~m}$ diameter, from which bottoms have been removed, according to Jantalia et al. (2012). Inside each bottle, a $70 \mathrm{~mL}$ plastic pot was hung and contained a polyethylene foam strip, moistened with $40 \mathrm{~mL}$ sulfuric acid solution $\left(1.5 \mathrm{~mol} \mathrm{~L}^{-1} \mathrm{H}_{2} \mathrm{SO}_{4}+4 \%\right.$ glycerol). These chambers were installed in the sowing lines, immediately after sowing, and were regularly replaced, when the foam strips were changed, allowing the soil under the chambers to receive the treatment with urea and irrigation. Foam strips were changed 19 times at June 11, 14, 18, 26; July 2, 8, 11, 14, 16, 21, 23, 25, 30; August 6, 13, 20, 28; and September 3, 10. Fluxes of $\mathrm{NH}_{3}-\mathrm{N}$ were calculated based on $\mathrm{N}$ recovery of $57 \%$ for field conditions, according to Araújo et al. (2009).

Soil moisture, ammonium $\left(\mathrm{NH}_{4}^{+}\right)$and nitrate $\left(\mathrm{NO}_{3}^{-}\right)$ concentrations were determined from $100 \mathrm{~g}$ soil samples collected within $0.5 \mathrm{~m}$ soil depth simultaneously with $\mathrm{N}_{2} \mathrm{O}-\mathrm{N}$ flux sampling. Around $10 \mathrm{~g}$ of soil was weighed, before and after drying in an oven for 24 hours at $105^{\circ} \mathrm{C}$. Soil moisture $\left(\mathrm{cm}^{3} \mathrm{~cm}^{-3}\right)$ was calculated considering the soil bulk density $\left(\mathrm{g} \mathrm{cm}^{-3}\right)$ determined for each treatment (Table 1). The available $\mathrm{NH}_{4}{ }^{+}$and $\mathrm{NO}_{3}{ }^{-}$were determined according to Mulvaney (1996).

Table 1. Soil properties of a clayey Rhodic Ferralsol cultivated with irrigated common-bean under no-tillage with or without mulching, and in a noncultivated area (Cerrado), at $0-0.1 \mathrm{~m}, 0.1-0.3$, and $0.3-0.5$ soil depths.

\begin{tabular}{|c|c|c|c|c|c|c|c|c|c|c|c|}
\hline \multirow[t]{2}{*}{ Treatment } & \multirow{2}{*}{$\begin{array}{c}\mathrm{pH} \\
\text { water }\end{array}$} & $\mathrm{Ca}$ & $\mathrm{Mg}$ & $\mathrm{H}+\mathrm{Al}$ & $\mathrm{P}$ & $\mathrm{K}$ & SOM & Clay & Silt & Sand & \\
\hline & & \multicolumn{3}{|c|}{--------( $\left.\mathrm{cmol}_{\mathrm{c}} \mathrm{dm}^{-3}\right)^{--------}$} & \multicolumn{2}{|c|}{$----\left(\mathrm{mg} \mathrm{dm}^{-3}\right)----$} & $\left(\mathrm{g} \mathrm{dm}^{-3}\right)$ & \multicolumn{3}{|c|}{ 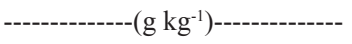 } & $\left(\mathrm{g} \mathrm{cm}^{-3}\right)$ \\
\hline & \multicolumn{11}{|c|}{$0-0.1-\mathrm{m}$ soil depth } \\
\hline Mulching & 5.36 & 0.86 & 0.40 & 7.4 & 46.8 & 156.75 & 22 & 509 & 80 & 411 & 1.47 \\
\hline Without mulching & 5.45 & 1.05 & 0.41 & 7.7 & 65.2 & 114.75 & 22 & 554 & 110 & 336 & 1.48 \\
\hline \multirow[t]{2}{*}{ Cerrado } & 5.10 & 0.18 & 0.10 & 8.0 & 1.5 & 0.08 & 40 & 600 & 100 & 300 & 0.96 \\
\hline & \multicolumn{11}{|c|}{$0.1-0.3-\mathrm{m}$ soil depth } \\
\hline Mulching & 4.79 & 0.35 & 0.13 & 6.1 & 9.8 & 57.88 & 16 & 529 & 100 & 371 & 1.47 \\
\hline Without mulching & 4.66 & 0.19 & 0.11 & 5.8 & 6.9 & 49.88 & 17 & 592 & 110 & 298 & 1.51 \\
\hline \multirow[t]{2}{*}{ Cerrado } & 4.60 & 0.15 & 0.10 & 4.7 & 1.2 & 0.06 & 18 & 600 & 90 & 310 & 1.10 \\
\hline & \multicolumn{11}{|c|}{$0.3-0.5-\mathrm{m}$ soil depth } \\
\hline Mulching & 5.06 & 0.43 & 0.15 & 3.6 & 1.3 & 39.38 & 10 & 549 & 100 & 351 & 1.25 \\
\hline Without mulching & 5.14 & 0.43 & 0.14 & 3.2 & 0.9 & 54.13 & 11 & 609 & 110 & 281 & 1.40 \\
\hline Cerrado & 5.10 & 0.10 & 0.10 & 2.5 & 0.8 & 0.03 & 10 & 650 & 70 & 280 & 1.09 \\
\hline
\end{tabular}

SOM, soil organic matter; $\rho b$, soil bulk density. 
Soil microbial biomass was quantified from $200 \mathrm{~g}$ soil samples collected within $0.1 \mathrm{~m}$ soil depth, during common-bean flowering stage (56 DAS). $\mathrm{N}$ and $\mathrm{C}$ in the soil microbial biomass were determined by fumigation and extraction methods (Brookes et al., 1985; Vance et al., 1987).

Seventeen days after sowing the common-bean, maize crop residues or Congo signal grass mulch were collected in four spots of $0.08 \mathrm{~m}^{2}$ within each treatment, in order to determine total dry matter mass, and total $\mathrm{C}$ and $\mathrm{N}$ content, using an elemental analyzer 2400 Series II CHNS/O (Perkin Elmer, São Paulo, SP, Brazil).

The analysis of variance was done using the generalized linear model procedure (Proc GLM) of SAS/STAT (SAS Institute, Cary, NC, USA). To contrast treatment effects, we used the Tukey's Studentized range test (at 5\% probability). Correlations were determined between variables related to soil management and total emission of $\mathrm{N}_{2} \mathrm{O}-\mathrm{N}$ and $\mathrm{NH}_{3}-\mathrm{N}$; and a linear model was fitted to test whether the concentration of $\mathrm{N}_{2} \mathrm{O}$ inside the chambers was dependent on the time of incubation. The magnitude of correlations and linear adjustment were assessed with the squared Pearson correlation coefficient between observed and predicted values $\left(\mathrm{R}^{2}\right)$. Parameter estimates are shown with respective nominal significance value ( $p$-value) and standard error of estimates.

\section{Results and Discussion}

Approximately $34 \%$ of the $\mathrm{N}_{2} \mathrm{O}-\mathrm{N}$ measured fluxes were negative (lower than concentration of $\mathrm{N}_{2} \mathrm{O}$ in the air). Most (54\%) of the negative fluxes were measured in unfertilized areas (34\% in Cerrado and 20\% in unfertilized treatments). The concentration changes of $\mathrm{N}_{2} \mathrm{O}$ over time inside the chambers were not significant for all treatments, except for the treatments fertilized with mulching and without mulching or fertilizer (Figure 1). Apart of the low fluxes itself, damping of flux diffusion control, pressure effects, and leaking - a source of error when using static chambers (Kroon et al., 2008) - are possible reasons for the observed nonsignificance. However, manual static chambers were reported to be the best method to get a direct measurement of small-scale spatial variability because it works well under all climate conditions and it has low cost, although it requires high workload (Drösler
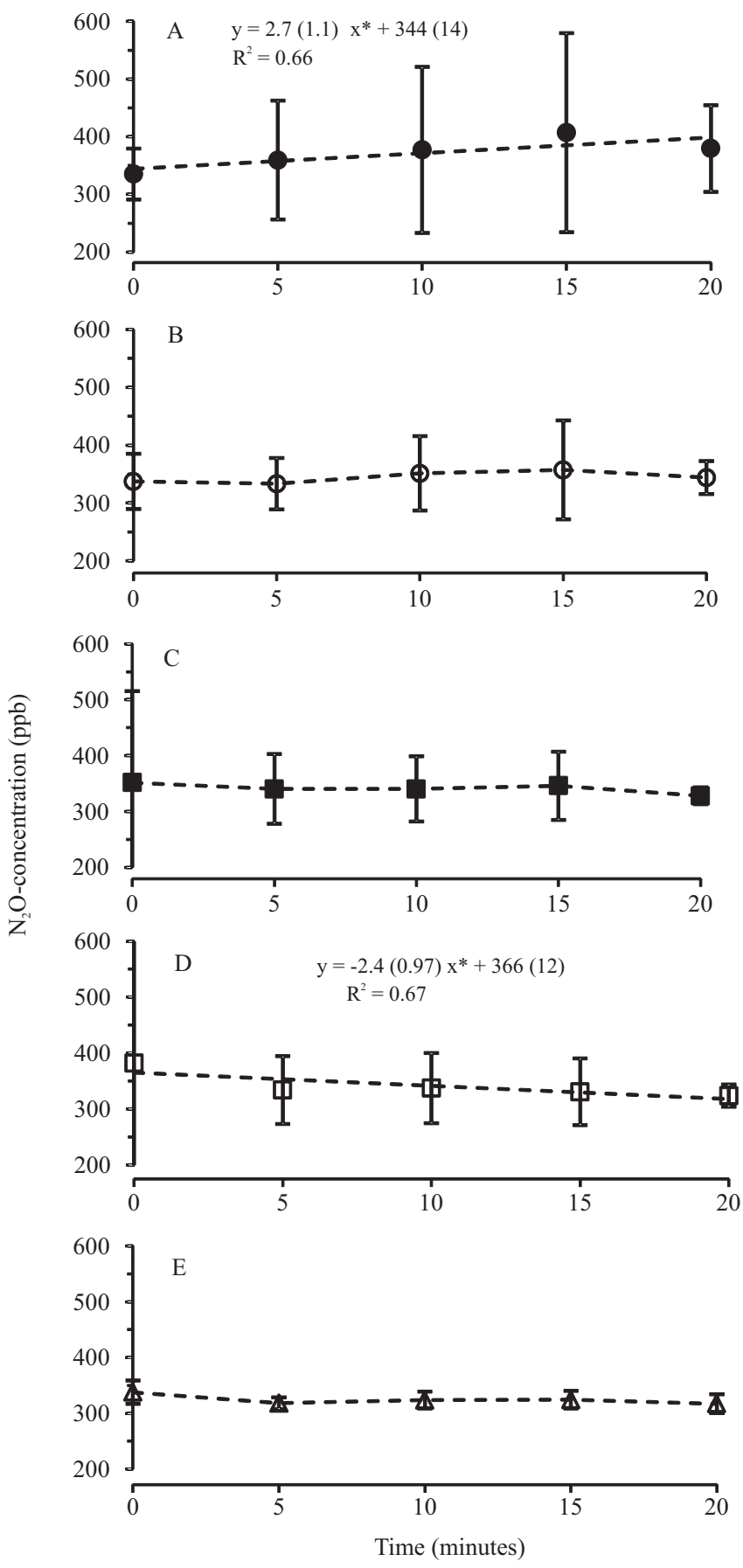

Figure 1. $\mathrm{N}_{2} \mathrm{O}$ accumulation into manual static chambers placed in an irrigated common-bean crop system under no-tillage: A, with Congo signal grass mulch and fertilizer; $\mathrm{B}$, with Congo signal grass mulch, without fertilizer; C, without Congo signal grass mulch and with fertilizer; D, without Congo signal grass mulch and without fertilizer; and E, noncultivated area (Cerrado). Black bars indicate the standard deviation of mean $(n=19)$; dotted lines represent the fitted linear model; values between brackets represent the standard error of estimate. *Significant at $10 \%$ probability. 
et al., 2008). Fluxes of $\mathrm{N}_{2} \mathrm{O}-\mathrm{N}\left(\mathrm{mg} \mathrm{m}^{-2}\right.$ per day) ranged from $-0.63 \pm 0.09$ (Cerrado) to $1.74 \pm 0.84$ (unfertilized mulching), and the ones of $\mathrm{NH}_{3}-\mathrm{N}$, from $4.66 \pm 2.44$ (Cerrado) to $62.85 \pm 12.52$ (fertilized mulching) (Figure 2).

Throughout the growing season, significantly higher $\mathrm{N}_{2} \mathrm{O}-\mathrm{N}$ fluxes occurred during $3(1.71 \pm 1.01)$, $31(0.47 \pm 0.34)$, and $79(0.24 \pm 0.07)$ days after sowing event (DAS), in the fertilized mulching; and during 3
$(1.74 \pm 0.85)$ and $79(0.18 \pm 0.21)$ DAS in the unfertilized mulching (Figure 2). Increasing soil moisture and available mineral $\mathrm{N}$ were the main causes for higher $\mathrm{N}_{2} \mathrm{O}-\mathrm{N}$ fluxes during 3 and 31 DAS in fertilized mulching. Passianoto et al. (2003) also observed higher $\mathrm{N}_{2} \mathrm{O}-\mathrm{N}$ losses in a nontilled soil covered by mulch, than in tilled soil, during the first week following mineral fertilization. However, cumulative fluxes of $\mathrm{N}_{2} \mathrm{O}-\mathrm{N}$ during period 3 , after fertilization and irrigation (42 to
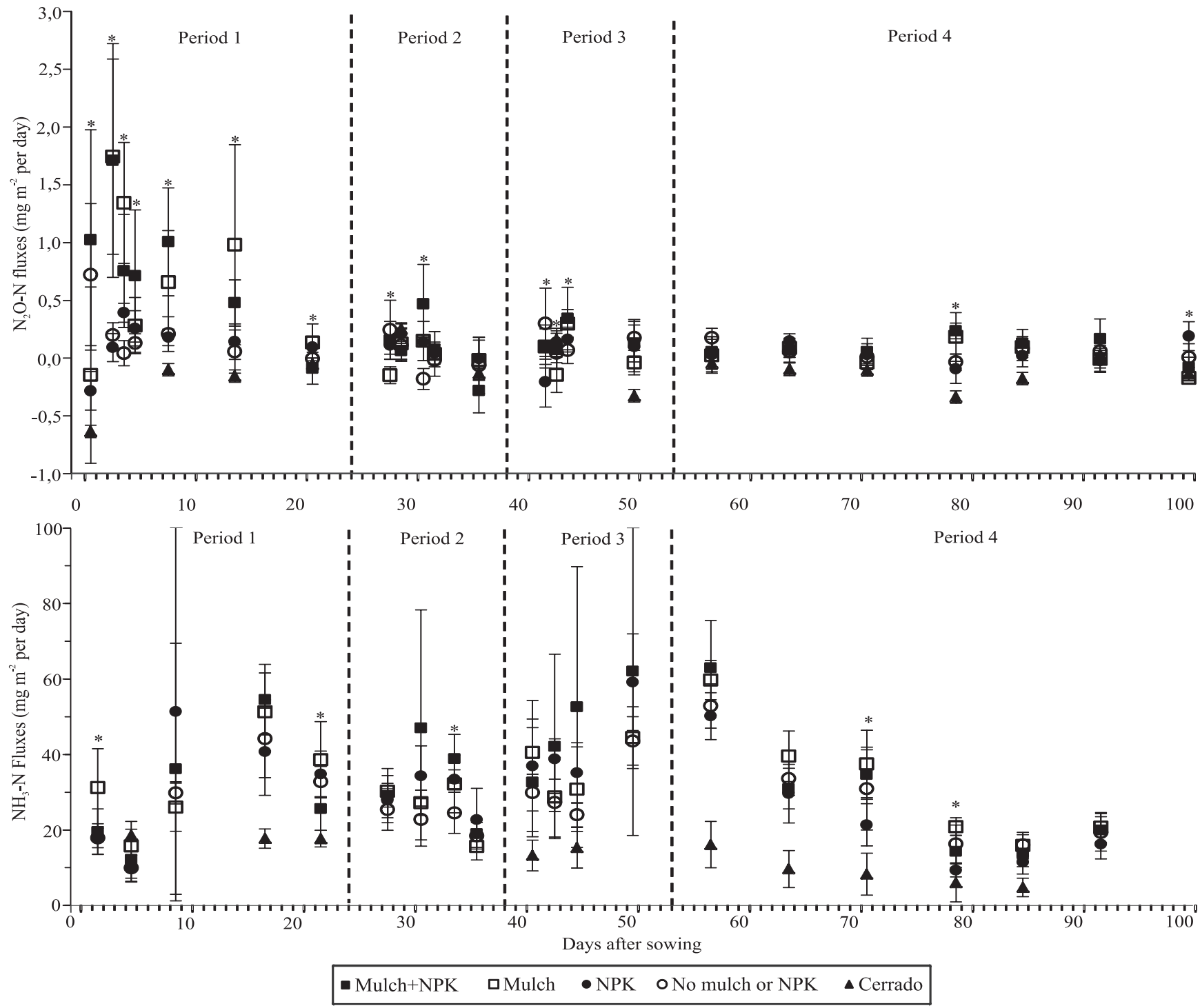

Figure 2. Fluxes of $\mathrm{N}_{2} \mathrm{O}-\mathrm{N}$ and $\mathrm{NH}_{3}-\mathrm{N}$ throughout the growing season of irrigated common-bean under no-tillage: with Congo signal grass mulch and fertilizer ( $\bullet$ Mulch+NPK); with mulch and no fertilizer (Mulch); without mulch, and with fertilizer $(\bullet N P K)$; without mulch of Congo signal grass, and without fertilizer ( $\circ$ No mulch or NPK); and from a noncultivated area ( $\boldsymbol{\Lambda}$ Cerrado). Dotted lines 1, 2, and 3 indicate the periods after mineral $\mathrm{N}$ fertilization; and period 4 indicates crop maturity, when no fertilization was applied. Bars represent standard deviation of means $(\mathrm{n}=6)$. *Significant differences among treatments, except for the noncultivated area (Cerrado), within each DAS, according to Tukey's Studentized test, at 5\% probability. 
50 DAS), were significantly higher than during period 1 (1 to $21 \mathrm{DAS})$, in the fertilized treatment without mulching, and were higher than during period 4 (57 to $100 \mathrm{DAS}$ ) in all treatments (Figure 3). Fluxes of $\mathrm{NH}_{3}-\mathrm{N}$, to the contrary, were more equally distributed over the growing season, with no significant difference for cumulative fluxes among periods for fertilized mulching. Moreover, no significant differences for $\mathrm{NH}_{3}-\mathrm{N}$ fluxes between fertilized and unfertilized treatments were detected. Cumulative fluxes were higher in period 3 than in period 2 for the fertilized treatment without mulching (Figure 3). Cumulative fluxes of $\mathrm{NH}_{3}-\mathrm{N}$ were significantly higher in period 4 (57 to 92 DAS), during crop maturity, than in periods 1,2 , and 3 , in the unfertilized treatments.

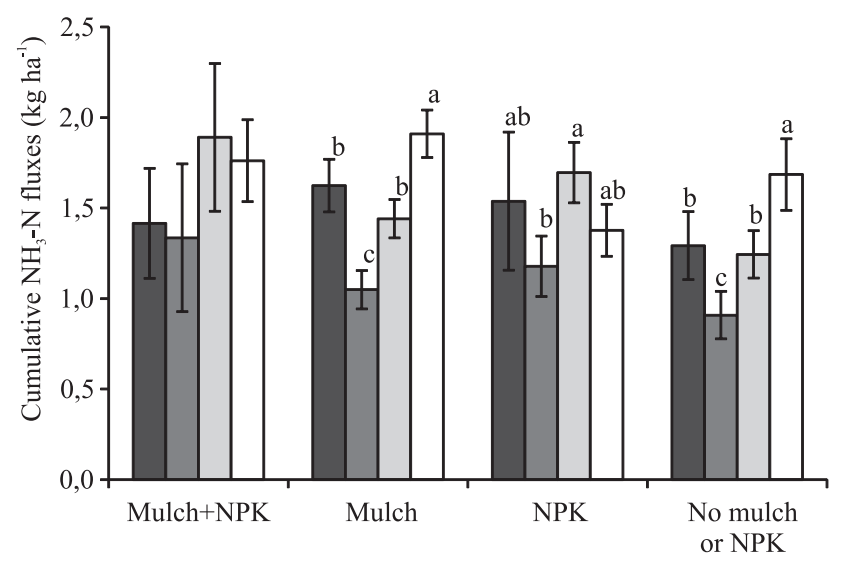

Total emitted $\mathrm{NH}_{3}-\mathrm{N}$ was not statistically different between fertilized and unfertilized treatments; however, it was significantly higher in the fertilized mulching than in the unfertilized treatment without mulching. Total emitted $\mathrm{N}_{2} \mathrm{O}-\mathrm{N}$ was significantly higher with Congo signal grass mulch than without it (Table 2). Total emission of both $\mathrm{N}_{2} \mathrm{O}-\mathrm{N}$ and $\mathrm{NH}_{3}-\mathrm{N}$ and the contents of moisture and nitrate within $0.5 \mathrm{~m}$ soil depth were significantly lower in the Cerrado than in the crop system (Table 2). Total emission of N-N $\mathrm{N}_{2} \mathrm{O}$ and $\mathrm{NH}_{3}-\mathrm{N}$ was positively correlated with contents of soil moisture, nitrate, and ammonium within $0.5 \mathrm{~m}$ soil depth. Total $\mathrm{N}_{2} \mathrm{O}-\mathrm{N}$ emission was positively correlated with total $\mathrm{C}$ added by mulch or crop residues, and with $\mathrm{C}$ and $\mathrm{N}$ in microbial biomass within $0.1 \mathrm{~m}$ soil depth

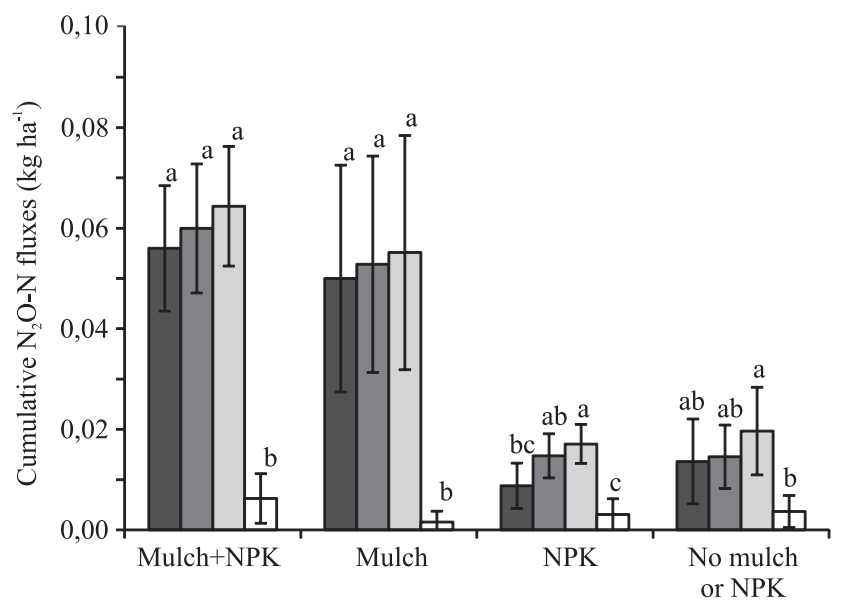

$\square$ Period $1 \quad \square$ Period 2 aPeriod 3 aPeriod 4

Figure 3. Cumulative $\mathrm{N}_{2} \mathrm{O}-\mathrm{N}$ and $\mathrm{NH}_{3}-\mathrm{N}$ fluxes within four periods over growing season of irrigated common-bean under no-tillage, with or without mulching and mineral fertilization (NPK). Periods after fertilization and irrigation are represented by the periods 1, 2 and 3; and crop maturity, by period 4, when no fertilization was applied. Bars represent standard deviation of mean $(n=6)$. Values followed by the same letter are not significantly different, according to Tukey's Studentized test, at $5 \%$ probability.

Table 2. Total $\mathrm{N}_{2} \mathrm{O}-\mathrm{N}$ and $\mathrm{NH}_{3}-\mathrm{N}$ emissions, soil moisture within $0.5 \mathrm{~m}$ soil depth, concentration of soil nitrate $\left(\mathrm{N}^{-\mathrm{NO}_{3}}{ }^{-}\right)$and ammonium (N-NH${ }_{4}^{+}$) within $0.5 \mathrm{~m}$ depth, carbon (CMB) and nitrogen (NMB) in soil microbial biomass within $0.1 \mathrm{~m}$ depth, and total carbon and nitrogen in mulch and crop residues, in an irrigated common-bean crop system under no-tillage ${ }^{(1)}$.

\begin{tabular}{|c|c|c|c|c|c|c|c|c|c|}
\hline \multirow[t]{3}{*}{ Treatment } & \multicolumn{2}{|c|}{ Emitted } & \multirow{3}{*}{$\begin{array}{l}\text { Soil moisture } \\
\left(\mathrm{cm}^{3} \mathrm{~cm}^{-3}\right)\end{array}$} & \multirow[t]{3}{*}{$\mathrm{N}^{-\mathrm{NO}_{3}}{ }^{-}$} & \multirow[t]{2}{*}{$\mathrm{N}-\mathrm{NH}_{4}^{+}$} & \multirow[t]{2}{*}{ CMB } & \multirow[t]{3}{*}{ NMB } & \multicolumn{2}{|c|}{ Mulch or residues } \\
\hline & $\mathrm{N}_{2} \mathrm{O}-\mathrm{N}$ & $\mathrm{NH}_{3}-\mathrm{N}$ & & & & & & Total C & Total $\mathrm{N}$ \\
\hline & \multicolumn{2}{|c|}{--(kg ha-1 per season)-- } & & & -----(m & )-------- & & \multicolumn{2}{|c|}{-----(Mg ha-1)---- } \\
\hline$\overline{M u l c h+N P K}$ & $0.229 a$ & $6.40 \mathrm{a}$ & $0.98 b$ & $329 b$ & $115 \mathrm{ab}$ & $413 a b$ & $45 \mathrm{~b}$ & $0.9 \mathrm{~b}$ & $0.014 \mathrm{~b}$ \\
\hline Mulch & $0.213 \mathrm{a}$ & $6.03 \mathrm{ab}$ & $0.99 b$ & $244 \mathrm{c}$ & $120 \mathrm{a}$ & $377 \mathrm{abc}$ & $41 b$ & $1.1 \mathrm{~b}$ & $0.020 \mathrm{~b}$ \\
\hline NPK & $0.107 \mathrm{~b}$ & $5.79 \mathrm{ab}$ & $1.00 \mathrm{~b}$ & $383 a$ & $119 \mathrm{a}$ & $288 \mathrm{bc}$ & $39 b$ & $0.8 \mathrm{~b}$ & $0.026 \mathrm{~b}$ \\
\hline No Mulch or NPK & $0.094 \mathrm{~b}$ & $5.13 b$ & $1.04 \mathrm{a}$ & $291 b$ & $119 \mathrm{a}$ & $239 \mathrm{c}$ & $38 b$ & $0.6 \mathrm{~b}$ & $0.007 b$ \\
\hline Cerrado & $0.001 \mathrm{c}$ & $1.22 \mathrm{c}$ & $0.62 \mathrm{c}$ & $62 \mathrm{~d}$ & $105 \mathrm{~b}$ & $482 \mathrm{a}$ & $76 \mathrm{a}$ & $4.9 \mathrm{a}$ & $0.104 \mathrm{a}$ \\
\hline$\overline{\mathrm{CV}}(\%)$ & 34 & 21 & 0.97 & 5 & 3 & 21 & 15 & 51 & 48 \\
\hline
\end{tabular}

${ }^{(1)}$ Values followed by the equal letters are not significantly different, according to Tukey's Studentized test, at $5 \%$ probability. 
(Table 3). Carbon in microbial biomass for treatments with mulch was equivalent to that observed in the Cerrado (Table 2), meaning that the soil under this mulch was as biologically active as the Cerrado soil. Because of the irrigation, however, soil moisture was higher in the crop system.

In an irrigated crop system, the amount of water applied can be associated with the magnitude of $\mathrm{N}_{2} \mathrm{O}-\mathrm{N}$ emission (Scheer et al., 2012). In the same Ferralsol of the present study, Metay et al. (2007) observed that $\mathrm{N}_{2} \mathrm{O}-\mathrm{N}$ fluxes were positively related to increasing water-filled pore space. Zanatta et al. (2010) found the highest fluxes of $\mathrm{N}_{2} \mathrm{O}-\mathrm{N}$ during 45 days after soil management associated with high water-filled pore space and increased organic $\mathrm{C}$ and mineral $\mathrm{N}$, which accounted for $30 \%$ of $\mathrm{N}_{2} \mathrm{O}-\mathrm{N}$ emissions in a year. During two years of field experiment, Jantalia et al. (2008) observed the highest fluxes of $\mathrm{N}_{2} \mathrm{O}-\mathrm{N}$ after periods of high rainfall associated with mineral fertilization. However, the $\mathrm{C}$ content in the mulch and microbial activity, favoured by the Congo signal grass, induced a higher emission of $\mathrm{N}_{2} \mathrm{O}-\mathrm{N}$ in treatments with mulching, regardless of $\mathrm{N}$ fertilization. The presence of mulch has been considered important for high $\mathrm{N}_{2} \mathrm{O}-\mathrm{N}$ emissions in no tillage systems (Gomes et al., 2009). Baggs et al. (2003) reported that surface-mulching residues of rye resulted in higher $\mathrm{N}_{2} \mathrm{O}-\mathrm{N}$ losses than with the incorporation of residues. They attributed this result to the degradable $\mathrm{C}$ of rye in the presence of anaerobic conditions under mulch. Available organic $\mathrm{C}$, associated with increasing water-filled pore space, can induce anaerobic sites, which can enhance

Table 3. Pearson correlation coefficients representing the relationship between total emission of $\mathrm{N}\left(\mathrm{N}_{2} \mathrm{O}-\mathrm{N}+\mathrm{NH}_{3}-\mathrm{N}\right)$ and soil management variables in an irrigated common-bean crop system under no-tillage ${ }^{(1)}$.

\begin{tabular}{|c|c|c|c|c|}
\hline \multirow[t]{2}{*}{ Variable } & \multicolumn{2}{|c|}{ Including the Cerrado } & \multicolumn{2}{|c|}{ Excluding the Cerrado } \\
\hline & $\mathrm{N}_{2} \mathrm{O}-\mathrm{N}$ & $\mathrm{NH}_{3}-\mathrm{N}$ & $\mathrm{N}_{2} \mathrm{O}-\mathrm{N}$ & $\mathrm{NH}_{3}-\mathrm{N}$ \\
\hline Soil moisture $\left(\mathrm{cm}^{3} \mathrm{~cm}^{-3}\right)$ & $0.5795^{* *}$ & $0.9339^{* * *}$ & $-0.4854^{\mathrm{ns}}$ & $-0.4552^{\mathrm{ns}}$ \\
\hline Soil N-NO-3 $\left(\mathrm{mg} \mathrm{kg}^{-1}\right)$ & $0.5279^{* *}$ & 0.895 & $-0.1402^{\mathrm{ns}}$ & $0.2768^{\text {ns }}$ \\
\hline Soil N-NH ${ }_{4}^{+}\left(\mathrm{mg} \mathrm{kg}^{-1}\right)$ & $0.4553^{*}$ & $0.7797^{* * *}$ & $-0.1643^{\mathrm{ns}}$ & $-0.1084^{\mathrm{ns}}$ \\
\hline $\mathrm{CBM}\left(\mathrm{mg} \mathrm{kg}^{-1}\right)$ & $-0.0633^{\mathrm{ns}}$ & $-0.4528^{* *}$ & $0.5924^{* * *}$ & $0.2880^{\text {ns }}$ \\
\hline $\mathrm{NBM}\left(\mathrm{mg} \mathrm{kg}^{-1}\right)$ & $-0.4992^{* *}$ & $-0.8100^{* * *}$ & $0.3997^{*}$ & $0.2819^{\text {ns }}$ \\
\hline Total C $\left(\mathrm{Mg} \mathrm{ha}^{-1}\right)$ & $-0.5021^{* *}$ & $-0.8368^{* * *}$ & $0.4620^{*}$ & $0.1815^{\text {ns }}$ \\
\hline Total N $\left(\mathrm{Mg} \mathrm{ha}^{-1}\right)$ & $-0.5301^{* * *}$ & $-0.8465^{* * *}$ & $0.2375^{\mathrm{ns}}$ & $0.2914^{\text {ns }}$ \\
\hline
\end{tabular}

${ }^{(1)} \mathrm{CBM}$ and $\mathrm{NBM}, \mathrm{C}$ and $\mathrm{N}$ in microbial biomass measured within $0.1 \mathrm{~m}$ soil depth; total $\mathrm{C}$ and $\mathrm{N}$, measured from Congo signal grass mulch and crop residues, after 17 days from sowing. ${ }^{\text {ns }}$ Nonsignificant. $* * *, * *$ and *Significant at 1,5 , and $10 \%$ probability, respectively. denitrification of the available nitrate in soil, resulting in high $\mathrm{N}_{2} \mathrm{O}-\mathrm{N}$ fluxes in no tillage system (Giacomini et al., 2006).

Nitrogen losses $\left(\mathrm{N}_{2} \mathrm{O}-\mathrm{N}+\mathrm{NH}_{3}-\mathrm{N}\right)$ from the applied mineral $\mathrm{N}$ (emission factor) varied from $0.01 \%$ (fertilized without mulching) to $0.02 \%$ (fertilized mulching) for $\mathrm{N}_{2} \mathrm{O}-\mathrm{N}$, and from $0.3 \%$ (fertilized mulching) to $0.6 \%$ (fertilized without mulching) for $\mathrm{NH}_{3}-\mathrm{N}$. These values were much lower than the default value proposed by the Intergovernmental Panel on Climate Change (IPCC), which is $1 \%$ for $\mathrm{N}_{2} \mathrm{O}-\mathrm{N}$, ranging from $0.3 \%$ to $3 \%$; and $10 \%$ for $\mathrm{NH}_{3}-\mathrm{N}$, ranging from 3 to $30 \%$. In an irrigated common-bean crop system in the Brazilian Cerrado, with broadcasted urea, Cruvinel et al. (2011) found an emission factor for $\mathrm{N}_{2} \mathrm{O}-\mathrm{N}$ of $0.20 \%$. The emission of $\mathrm{N}_{2} \mathrm{O}-\mathrm{N}$ found in the present study was equivalent to that measured by Metay et al. (2007) of $0.03 \%$, in a rainfed rice crop system under no tillage, with Congo signal grass mulch, in a Cerrado Ferralsol. Literature information on $\mathrm{NH}_{3}-\mathrm{N}$ fluxes is rather variable, since they are often obtained through different methodologies. Using semi open static chambers, Da Ros et al. (2005) observed 17\% $\mathrm{NH}_{3}-\mathrm{N}$ losses of the urea broadcasted on crop residues, in a subtropical Acrisol, in Southern Brazil. Using open chambers, Jantalia et al. (2012) observed $1.9 \%$ to $2.4 \%$ $\mathrm{NH}_{3}-\mathrm{N}$ losses of the urea broadcasted in an irrigated system. Turner et al. (2012) found $\mathrm{NH}_{3}-\mathrm{N}$ losses ranging from 1.8 to $23 \%$ of the added $\mathrm{N}$ fertilizers in different cropping systems. They attributed the variability of these results to soil-climate conditions, such as soil moisture, temperatures, and wind speed. Due to the wide range of values that can be obtained, estimation of $\mathrm{N}$ losses from fertilizer application in crop systems is challenging.

\section{Conclusions}

1. Carbon content of the mulch and soil microbial activity, both favoured by Urochloa ruziziensis, enhances the emissions of $\mathrm{N}_{2} \mathrm{O}-\mathrm{N}$ in treatments with mulching, regardless of $\mathrm{N}$ fertilization.

2. Total $\mathrm{N}_{2} \mathrm{O}-\mathrm{N}$ and $\mathrm{NH}_{3}-\mathrm{N}$ emissions are positively related to the concentrations of moisture, ammonium, and nitrate within $0.5 \mathrm{~m}$ soil depth, when mineral fertilization is used.

3. Emission factors for $\mathrm{N}_{2} \mathrm{O}-\mathrm{N}$ and $\mathrm{NH}_{3}-\mathrm{N}$ under the conditions of this study were lower than the default value recognized by the Intergovernmental Panel on Climate Change. 


\section{Acknowledgments}

To Challenge Program on Climate Change (CGIAR), to Agriculture and Food Security (CCAFS), and to the Faculty of Life Sciences, University of Copenhagen, for providing funds; to Bruno José Rodrigues Alves and João Eudes Santana Lima, whose advices were important to enable this study; to Jaison Pereira Oliveira and Aline de Holanda Nunes Maia, for guidance on data analysis; and to Prof. Holger Meinke and Pepijn A.J. van Oort, who kindly revised the scientific content.

\section{References}

ALVES, B.J.R.; SMITH, K.A.; FLORES, R.A.; CARDOSO, A.S.; OLIVEIRA, W.R.D.; JANTALIA, C.P.; URQUIAGA, S.; BODDEY, R.M. Selection of the most suitable sampling time for static chambers for the estimation of daily mean $\mathrm{N}_{2} \mathrm{O}$ flux from soils. Soil Biology and Biochemistry, v.46, p.129-135, 2012. DOI: 10.1016/j.soilbio.2011.11.022.

ARAÚJO, E. da S.; MARSOLA, T.; MIYAZAWA, M.; SOARES, L.H.B.; URQUIAGA, S.; BODDEY, R.M.; ALVES, B.J.R. Calibração de câmara semiaberta estática para quantificação de amônia volatilizada do solo. Pesquisa Agropecuária Brasileira, v.44, p.769-776, 2009. DOI: 10.1590/S0100-204X2009000700018.

BAGGS, E.M.; STEVENSON, M.; PIHLATIE, M.; REGAR, A.; COOK, H.; CADISCH, G. Nitrous oxide emissions following application of residues and fertiliser under zero and conventional tillage. Plant and Soil, v.254, p.361-370, 2003. DOI: 10.1023/A:1025593121839.

BARDGETT, R.D.; FREEMAN, C.; OSTLE, N.J. Microbial contributions to climate change through carbon cycle feedbacks. The International Society for Microbial Ecology Journal, v.2, p.805-814, 2008. DOI: 10.1038/ismej.2008.58.

BROOKES, P.C.; LANDMAN, A.; PRUDEN, G.; JENKINSON, D.S. Chloroform fumigation and the release of soil nitrogen: a rapid direct extraction method to measure soil microbial biomass nitrogen in soil. Soil Biology and Biochemistry, v.17, p.837-842, 1985. DOI: 10.1016/0038-0717(85)90144-0.

CARVALHO, A.M. de; BUSTAMANTE, M.M. da C.; KOZOVITS, A.R.; MIRANDA, L.N.; VIVALDI, L.J.; SOUSA, D.M. Emissão de óxidos de nitrogênio associada à aplicação de uréia sob plantio convencional e direto. Pesquisa Agropecuária Brasileira, v.41, p.679-685, 2006. DOI: 10.1590/S0100-204X2006000400020.

CERRI, C.C.; MAIA, S.M.F.; GALDOS, M.V.; CERRI, C.E.P.; FEIGL, B.J.; BERNOUX, M. Brazilian greenhouse gas emissions: the importance of agriculture and livestock. Scientia Agricola, v.66, p.831-843, 2009. DOI: 10.1590/S0103-90162009000600017.

CRUVINEL, E.B.F.; BUSTAMANTE, M.M. da C.; KOZOVITS, A.R.; ZEPP, R.G. Soil emissions of $\mathrm{NO}, \mathrm{N}_{2} \mathrm{O}$ and $\mathrm{CO}_{2}$ from croplands in the savanna region of central Brazil. Agriculture
Ecosystems and Environment, v.144, p.29-40, 2011. DOI: 10.1016/j.agee.2011.07.016.

DA ROS, C.O.; AITA, C.; GIACOMINI, S.J. Volatilização de amônia com aplicação de uréia na superfície do solo, no sistema plantio direto. Ciência Rural, v.35, p.799-805, 2005. DOI: 10.1590/S0103-84782005000400008.

DRÖSLER, M.; FREIBAUER, A.; CHRISTENSEN, T.R.; FRIBORG, T. Observations and status of peatland greenhouse gas emissions in Europe. In: DOLMAN, J.; VALENTINI, R.; FREIBAUER, A. (Ed.). The continental-scale greenhouse gas balance of Europe. Springer eBooks, 2008. p.243-261. (Ecological studies, 203).

GIACOMINI, S.J.; JANTALIA, C.P.; AITA, C.; URQUIAGA, S.S.; ALVES, B.J.R. Emissão de óxido nitroso com a aplicação de dejetos líquidos de suínos em solo sob plantio direto. Pesquisa Agropecuária Brasileira, v.41, p.1653-1661, 2006. DOI: 10.1590/ S0100-204X2006001100012.

GOMES, J.; BAYER, C.; COSTA, F. de S.; PICCOLO, M.C.; ZANATTA, J.A.; VIEIRA, F.C.B.; SIX, J. Soil nitrous oxide emissions in long-term cover crops-based rotations under subtropical climate. Soil and Tillage Research, v.106, p.36-44, 2009. DOI: 10.1016/j.still.2009.10.001.

JANTALIA, C.P.; HALVORSON, A.D.; FOLLETT, R.F.; ALVES, B.J.R.; POLIDORO, J.C.; URQUIAGA, S. Nitrogen source effects on ammonia volatilization as measured with semi-static chambers. Agronomy Journal, v.104, p.1595-1603, 2012. DOI: 10.2134/ agronj2012.0210.

JANTALIA, C.P.; SANTOS, H.P.; URQUIAGA, S.; BODDEY, R.M.; ALVES, B.J.R. Fluxes of nitrous oxide from soil under different crop rotations and tillage systems in the South of Brazil. Nutrient Cycling in Agroecosystems, v.82, p.161-173, 2008. DOI: 10.1007/s10705-008-9178-y.

KROON, P.S.; HENSEN, A.; VAN DEN BULK, W.C.M.; JONGEJAN, P.A.C.; VERMEULEN, A.T. The importance of reducing the systematic error due to non-linearity in $\mathrm{N}_{2} \mathrm{O}$ flux measurements by static chambers. Nutrient Cycling in Agroecosystems, v.82, p.175-186, 2008. DOI: 10.1007/ s10705-008-9179-X.

METAY, A.; OLIVER, R.; SCOPEL, E.; DOUZET, J.-M.; MOREIRA, J.A.A.; MARAUX, F.; FEIGL, B.J.; FELLER, C. $\mathrm{N} 2 \mathrm{O}$ and $\mathrm{CH} 4$ emissions from soils under conventional and no-till management practices in Goiania (Cerrados, Brazil). Geoderma, v.141, p.78-88, 2007. DOI: 10.1016/j.geoderma.2007.05.010.

MULVANEY, R.L. Nitrogen: inorganic forms. In: SPARKS, D.L. (Ed.). Methods of soil analysis. Part 3. Chemical methods. Madison: SSSA, 1996. p.1162-1171.

NATIONAL COMPANY OF FOOD SUPPLY. Brazilian crop assessment - grain - crop 2012/2013 ninth assessment Jun/2013. Brasília: Conab, 2013. 30p. Available at: <http://www. conab.gov.br/OlalaCMS/uploads/arquivos/13_06_12_10_36_58_ boletim_ingles_junho_2013.pdf $>$. Accessed on: 18 June 2013.

PASSIANOTO, C.C.; AHRENS, T.; FEIGL, B.J.; STEUDLER, P.A.; CARMO, J.B.; MELILLO, J.M. Emissions of $\mathrm{CO}_{2}, \mathrm{~N}_{2} \mathrm{O}$, and $\mathrm{NO}$ in conventional and no-till management practices in Rondônia, 
Brazil. Biology and Fertility of Soils, v.38, p.200-208, 2003. DOI: 10.1007/S00374-003-0653-Y.

PÉREZ, T.; TRUMBORE, S.E.; TYLER, S.C.; MATSON, P.A.; ORTIZ-MONASTEIRO, I.; RAHN, T.; GRIFFITH, D.W.T. Identifying the agricultural imprint on the global $\mathrm{N}_{2} \mathrm{O}$ budget using stable isotopes. Journal of Geophysical Research, v.106, p.9869-9878, 2001. DOI: 10.1029/2000JD900809.

PIVA, J.T.; DIECKOW, J.; BAYER, C.; ZANATTA, J.A.; MORAES, A.; PAULETTI, V.; TOMAZI, M.; PERGHER, M. No-till reduces global warming potential in a subtropical Ferralsol. Plant and Soil, v.361, p.359-373, 2012. DOI: 10.1007/ s11104-012-1244-1.

POSSE, S.C.P.; RIVA-SOUZA, E.M.; SILVA, G.M.; FASOLO, L.M.; SILVA, M.B.; ROCHA, M.A.M. Technical information for cultivating common-bean in Brazilian central region. Vitória: Incaper, 2011. 245p. (Incaper. Documents, 191).

REAY, D.S.; DAVIDSON, E.A.; SMITH, K.A.; SMITH, P.; MELILlO, J.M.; DENTENER, F.; CRUTZEN, P.J. Global agriculture and nitrous oxide emissions. Nature Climate Change, v.2, p.410-416, 2012. DOI: 10.1038/nclimate1458.

ROCHETTE, P. No-till only increases $\mathrm{N}_{2} \mathrm{O}$ emissions in poorly-aerated soils. Soil and Tillage Research, v.101, p.97-100, 2008. DOI: 10.1016/j.still.2008.07.011.
SCHEER, C.; GRACE, P.R.; ROWLINGS, D.W.; PAYERO, J. Nitrous oxide emissions from irrigated wheat in Australia: impact of irrigated management. Plant and Soil, v.359, p.351-362, 2012. DOI: $10.1007 / \mathrm{s} 11104-012-1197-4$.

SILVA, F.C. da. (Ed.). Manual de análises químicas de solos, plantas e fertilizantes. 2.ed. Brasília: Embrapa Informação Tecnológica; Rio de Janeiro: Embrapa Solos, 2009. 627p.

TURNER, D.A.; EDIS, R.E.; CHEN, D.; FRENEY, J.R.; DENMEAD, O.T. Ammonia volatilization from nitrogen fertilizers applied to cereals in two cropping areas of Southern Australia. Nutrient Cycling in Agroecosystems, v.93, p.113-126, 2012. DOI: $10.1007 / \mathrm{s} 10705-012-9504-2$.

VANCE, E.D.; BROOKES, P.C.; JENKINSON, D.S. An extraction method for measuring soil microbial biomass C. Soil Biology and Biochemistry, v.19, p.703-707, 1987. DOI: 10.1016/0038-0717(87)90052-6.

WOODWARD, F.I.; BARDGETT, R.D.; RAVEN, J.A.; HETHERINGTON, A.M. Biological approaches to global environment change mitigation and remediation. Current Biology, v.19, p.R615-R623, 2009. DOI: 10.1016/j.cub.2009.06.012.

ZANATTA, J.A.; BAYER, C.; VIEIRA, F.C.B.; GOMES, J.; TOMAZI, M. Nitrous oxide and methane fluxes in South Brazilian Gleysol as affected by nitrogen fertilizers. Revista Brasileira de Ciência do Solo, v.54, p.1653-1665, 2010. DOI: 10.1590/ S0100-06832010000500018.

Received on Dezember 26, 2012 and accepted on April 17, 2013

Pesq. agropec. bras., Brasília, v.48, n.5, p.478-486, maio 2013 